https://doi.org/10.18778/7525-969-8.02

Michat Jerzy Zacharias

\title{
System komunistyczny w myśli politycznej Milovana Đilasa. Powstanie, charakter, przesłanki zaniku
}

Uważny czytelnik i analityk spuścizny pisarskiej Milovana Đilasa ${ }^{1} \mathrm{z}$ łatwością dostrzeże, że rozważania dotyczące różnych aspektów systemu komunistycznego stanowiły zasadniczą cechę jego myślenia politycznego. Đilas pisze o ideach, utopiach i rzeczywistości, w której zasadnicze założenia ustroju komunistycznego powstawały i ewoluowały, przybierając różne formy zależnie od czasu, miejsca i okoliczności. Analizuje także przesłanki, które mogły, a nawet musiały prowadzić do upadku systemu tworzonego przez komunistów. Zazwyczaj u podstaw jego analizy dostrzegamy wnikliwą obserwację wielowymiarowej, konkretnej sytuacji, konkretnej rzeczywistości. Zarówno tej, widocznej na obszarach byłej Jugosławii, jak i szerzej - w Europie i na świecie, przede wszystkim - w Związku Sowieckim. To właśnie obserwacje i przemyślenia dotyczące różnych grup społecznych i narodowych, egzystencji ludzkiej warunkowanej polityka, problemami gospodarczymi, sporami i konfliktami społecznymi, prowadziły Đilasa do prezentacji rozwiązań i propozycji ideologicznych, początkowo wspieranych siłą i orężem jugosłowiańskiej partii komunistycznej, do wiary w ich skuteczność i niezawodność jako środków służących poprawie, a nawet umożliwiających całkowitą zmianę aktualnej, kalekiej rzeczywistości. Rozwiązań i propozycji odrzucanych w miarę nabywanego przekonania, że traktowane jako panaceum na wszelkie zło świata sąjedynie fantomami, utopiami niezdolnymi wyplenić czy chociażby zmniejszyć słabości, wyraźne ułomności istniejącego porządku, konkretnego ustroju. Bezsilnymi w obliczu zacofania, wyzysku, nędzy, zniewolenia

${ }^{1}$ Milovan Đilas - polityk, pisarz, myśliciel jugosłowiański, urodzony w czarnogórskiej miejscowości Podbišće w czerwcu 1911 r., zmarły w kwietniu 1995 r. w Belgradzie, zob. M.J. Zacharias, Między marzeniami a rzeczywistościq. Myśl polityczna Milovana Djilasa na przełomie 1953 i 1954 r., „Dzieje Najnowsze” 2010, nr 3, s. 23 i n.; tenże, Idea i praktyka komunistyczna w myśli politycznej Milovana Djilasa (1911-1995), [w:] Historia, polityka, stosunki międzynarodowe. Wybrane zagadnienia, pod red. A. Zaćmińskiego, Bydgoszcz 2010, s. 11 i n. 
i dyskryminacji - społecznej, politycznej, narodowej. Co więcej, często jedynie pogłębiającymi te niekorzystne i niepożądane zjawiska.

Ostatecznie, różne analizy i obserwacje rzeczywistości, a w ich następstwie - przyjmowanie i odrzucanie ideologii oraz utopii sprawiały, że Đilas kolejno stawał się buntownikiem, stalinista, „heretykiem”, a po usunięciu ze Związku Komunistów Jugosławii (SKJ) i życia politycznego w swoim kraju w 1954 r. demaskatorem systemu komunistycznego - jednym z najwnikliwszych w drugiej połowie XX stulecia. Kończył życie jako demokrata świadomy, że ułomna rzeczywistość jest jedyną możliwą formą ludzkiej egzystencji, odporną na oddziaływanie jakiejkolwiek utopii, wprowadzanej siłą z myślą o radykalnym, całkowitym uzdrowieniu stosunków międzyludzkich.

Należy podkreślić, że o początkach myśli politycznej Đilasa dowiadujemy się jedynie z jego późniejszych wypowiedzi, wywiadów, przede wszystkim zaś książek $^{3}$. Nie jesteśmy więc $\mathrm{w}$ stanie stwierdzić $\mathrm{z}$ całą pewnościa, czy i w jakim stopniu te relacje są zgodne z jego młodzieńczymi przemyśleniami. W rezultacie musimy je przyjmować z pewną rezerwa, bardziej jako hipotezy niż rzeczywiste fakty. Pamiętając o naturalnej potrzebie każdego w istocie człowieka do przedstawiania się w jak najlepszym świetle oraz o słowach samego Đilasa odnoszących się, jak pisze, również do niego, że w naturze ludzkiej leży „pozbywanie się wszystkiego co zbyteczne”, a „zatrzymywanie tylko tego, co w świetle późniejszych wydarzeń okazywało się najważniejsze”. Także dlatego, że „słabą stroną” „natury” jest uleganie „nastrojom”, dostosowującym „minioną rzeczywistość do bieżacych potrzeb i przyszłych nadziei" ${ }^{4}$. Nie bez znaczenia musi być niechybnie również fakt, że Đilas był pisarzem, stylistą dbającym o taką formę swoich dzieł, która najlepiej, jak prawdopodobnie przypuszczał, przybliżałaby je czytelnikom, wywołując zainteresowanie, wywierając pożądany efekt. W tych warunkach nie

${ }^{2}$ Komunistycznym „heretykiem” z punktu widzenia ortodoksyjnych, stalinowskich władz w Moskwie. Można jednakże stwierdzić, że z czasem, po rozstaniu się ze swymi dotychczasowymi przyjaciółmi politycznymi, z Josipem Broz-Titą na czele, w 1954 r. Đilas stał się także swoistym „heretykiem w herezji”. Nie nawracając się bowiem na stalinizm, zaczął zwalczać również miejscowa, titowską wersję komunizmu.

${ }^{3}$ Mam na myśli przede wszystkim następujące pozycje: M. Djilas, The New Class. An Analysis of the Communist System, New York 1957; tenże, Land Without Justice. An Autobiography of His Youth, London 1958; Anatomy of a Moral. The Political Essays of Milovan Djilas, ed. by A. Rothberg with an introd. by P. Willen, London 1959 (dalej AM); tenże, Conversations with Stalin, New York 1962; tenże, The Unperfect Society. Beyond the New Class, New York 1969 (wersja francuska: Une societé imparfaite. Le communism désintegré, Paris 1969); tenże, Memoir of a Revolutionary, New York 1973; tenże, Wartime, New York 1977; tenże, Tito. The Story from Inside, London 1981; tenże, Rise and Fall, San Diego-New York-London 1985; tenże, Of Prisons and Ideas, San Diego-New York-London 1986; M. Đilas, Pad nove klase. Povest o samorazaranju komunizma, Beograd 1994.

${ }^{4}$ M. Dżilas, Rozmowy ze Stalinem, Paryż 1962, s. 10. 
można wykluczyć, że pewna fantazja, konfabulacje i literackie popisy mogły wpływać na treść relacji Đilasa, dotyczących jego pierwotnych, młodzieńczych przemyśleń i wyborów ideologicznych.

Pamiętając o powyższych zastrzeżeniach możemy jedynie stwierdzić, że swoją początkowa fascynację komunizmem w stalinowskiej formie Đilas wiąże z ponurymi wspomnieniami dzieciństwa w Czarnogórze, dotyczącymi odwiecznej rywalizacji różnych rodów i klanów, walki z Turcją i monarchią Habsburgów, w końcu zaś - I wojny światowej. Niewiele lepsze były - jak wynika $\mathrm{z}$ jego relacji - młodzieńcze doświadczenia nabyte w Jugosławii ${ }^{5}$, a więc $\mathrm{w}$ kraju zacofanym, biednym, pełnym wyzysku, przemocy, nierówności i zniewolenia szerokich mas ludowych. Istotne miało być również przekonanie, że w Jugosławii nie było żadnej siły politycznej zdolnej wpływać na zmianę tego stanu rzeczy ${ }^{6}$. Żadnej - oprócz komunistów. We wspomnieniach Đilas twierdzi, że komunizm był wówczas ideą nową „młodzieńczym entuzjazmem”, „życzeniem”, „wysiłkiem”, „poświęceniem”, gwarancja „lepszego, szczęśliwszego życia”. Paniczne starania „zachowania dawnych form i stosunków”, czynione przez „stróży status quo” w międzywojennej, królewskiej Jugosławii, mogły tylko pogłębiać przekonanie „młodego człowieka” o atrakcyjności „wielkiej rewolucji”, sprzyjającej „urzeczywistnieniu braterstwa i równości, zniesienia wyzysku ludzi pracy” oraz „zapewnienia im szczęśliwego życia”.

Takim nadziejom i fascynacjom towarzyszyła całkowita jeszcze nieznajomość myśli Karola Marksa i szerzej - myśli marksistowskiej. Đilas pozna ją dopiero później, szczególnie po wybuchu konfliktu z Moskwą z 1948 r., w rezultacie studiów i dyskusji ideologicznych w łonie jugosłowiańskiego kierownictwa partyjnego. Były one pokłosiem tego konfliktu. W latach 30. zaś nieznajomość myśli Marksa mogła jedynie ułatwiać, jak można przypuszczać, akceptację marksizmu w jego najbardziej uproszczonej, prymitywneji zwulgaryzowanejwersji. W praktyce - akceptację stalinizmu. Sprzyjała temu zapewne nieznajomość

${ }^{5}$ Nazwa tego państwa do stycznia 1929 r. - Królestwo Serbów, Chorwatów i Słoweńców (SHS).

${ }^{6}$ Zdaniem Đilasa społeczeństwo, narody w monarchii Karađorđeviciów, szczególnie zaś ugrupowania polityczne w tym kraju, nie były nawet zdolne do złożenia obietnicy urzeczywistnienia „bardziej humanitarnych i sprawiedliwych stosunków między ludźmi”, M. Djilas, Land Without Justice..., s. 299, 302-303.

7 Tamże, s. 302-303; tenże, Memoir of a Revolutionary..., s. 92-93.

8 Wspominając wczesne lata swojego życia Đilas pisze, że wynikało to głównie z dość prozaicznego faktu, a mianowicie braku „literatury marksistowskiej” w ,zacofanych i prymitywnych” miejscowościach Czarnogóry, tenże, Land Without Justice..., s. 299. U schyłku lat 70. XX w. Đilas tłumaczył swój akces do komunizmu poszukiwaniem miejsca, w którym jego buntownicza natura „mogłaby znaleźć ujście”. Przecież „rewolucjoniści są urodzonymi rewolucjonistami. Nie uczą się rewolucji z książek”. M. Dżilas, Chrystus i komisarz, [w:] Stalin i stalinizm. Rozmowy George'a Urbana, London 1987, s. 193. 
warunków życia w „kwitnącym sowieckim ogrodzie”, choćby z racji oddalenia i niemożliwości utrzymywania kontaktów z władzami i obywatelami „Kraju Rad”. Niewątpliwie mogła ona stać się jednym z powodów dostrzegania przez młodego Đilasa w „teorii” stalinowskiej ,żywego, duchowego uzbrojenia rewolucji”, nie mającego nic wspólnego z „wykastrowana, skamieniała forma”; traktowania przezeń komunizmu jako „absolutnej wolności”, komunistycznej zaś aktywności - jako ruchu, „naukowo odkrytego szlaku”, który miał do tej wolności prowadzić ${ }^{10}$.

Stalinowska postawa Đilasa, uformowana w latach 30., była widoczna głównie w czasie II wojny światowej i bezpośrednio po jej zakończeniu. Z jego późniejszych wspomnień wynikałoby, że, z pewnymi wszakże zastrzeżeniami, powstałymi w rezultacie słynnych „rozmów ze Stalinem” i konsekwencji zdobycia władzy przez komunistów w Jugosławii ${ }^{11}$. Niezależnie od tego, czy te wątpliwości i zastrzeżenia potraktujemy jako rzeczywiste fakty, czy tylko jako hipotezy, to musimy stwierdzić, że ewolucja ideowa Đilasa po konflikcie z 1948 r. ujawniła się istotnie. Wiemy o niej nie z późniejszych wypowiedzi „towarzysza Đido" ${ }^{\prime 2}$, ustnych i pisemnych, lecz z bieżących relacji - jego oraz innych komunistów jugosłowiańskich. Đilas stał się wówczas nieprzejednanym krytykiem przywódców jugosłowiańskiej rewolucji, przekształcających się w partyjnych biurokratów, stojących ponad prawem i państwem, ciemiężących i wyzyskujących masy ludowe i narody Jugosławii. Swoistym nosicielem „herezji w herezji” ${ }^{13}$, niedwuznacznie sugerujacym pozbawienie przywódców SKJ władzy, przywilejów, wielkich korzyści materialnych $^{14}$. W rezultacie wspomniana eliminacja jego osoby z życia politycznego i publicznego Jugosławii była logiczną konsekwencją takich sugestii i poglądów.

Nowa klasę, a więc najbardziej znane dzieło Đilasa, wydane w $1957 \mathrm{r}^{15}$, można i należy potraktować jako pracę najpełniej wyrażającą przyczyny potę-

9 Tak określano Związek Sowiecki m.in. w manifeście wzywającym narody Jugosławii do walki z okupantami po napaści III Rzeszy z 22 czerwca 1941 r., zob. Proglas CK KPJ povodom napada fašističke Nemačke na Sovjetski Savez, [w:] Komunistička partija Jugoslavije 1918-1941. Izabrani dokumenti, ur. E. Hasanagić, Zagreb 1954, s. 254-258.

${ }^{10}$ M. Đilas, Razvoj mog političkog mišljenja, http://milovandjilas/Tekstovi/razvoj\% 20mogpolitičkog\%20misljenja.pdf, cz. 3 .

11 Zob. M.J. Zacharias, Między marzeniami a rzeczywistościq..., s. 27 i n.; M. Đilas, Razvoj..., cz. 8 i 9.

12 Tak często nazywali Đilasa członkowie i przywódcy Komunistycznej Partii Jugosławii.

${ }_{13}$ Zob. przypis 2 prezentowanego artykułu. Przyczyna „herezji w herezji” Đilasa tkwiła w fakcie, że niedawny jeszcze podwładny i współpracownik Tity zaczał zdawać sobie sprawę, że także jugosłowiańska modyfikacja komunizmu nie jest w stanie przezwyciężyć stalinizmu.

${ }_{14}$ Zob. M.J. Zacharias, Między marzeniami a rzeczywistościq..., s. 34 i n.

15 Zob. przypis 3. Polskie tłumaczenia: M. Dżilas, Nowa klasa wyzyskiwaczy (analiza systemu komunistycznego), Paryż 1957; tenże, Nowa klasa. Analiza systemu komunistycznego, Nowy Jork 1958. Autor prezentowanego artykułu korzysta z tego ostatniego wydania. 
pienia przezeń komunizmu. Przede wszystkim jednakże jest ona jego najwnikliwszą analizą tego systemu, wyrastającego z powikłanej, skomplikowanej rzeczywistości. W dużym stopniu zdeterminowanej, poddanej oddziaływaniu różnych konieczności, ale także idei, często powiązanych ze skłonnościami do tworzenia utopijnych wizji, do budowy idealnego świata. Rzeczywistości analizowanej w zgodzie z marksowską (czy szerzej: marksistowska) teoria, przy użyciu jej pojęć, określeń, kategorii, wśród których poczesne miejsce zajmują idee postępu (rozwoju), przemian, przekształceń, uwagi dotyczące powstawania nowego układu stosunków społecznych. Wyłaniających się w rezultacie walki i oddziaływania sprzeczności, przeciwstawnych dążen różnych grup, warstw i klas, narodów i państw, mających sprzeczne interesy i wyrażających odmienne idee, poglądy oraz dążenia. To właśnie ta walka stanowi główną siłę napędową postępu, choć, jak wynika także z innych prac Đilasa, może niekiedy prowadzić na manowce, do zastoju, regresu, zacofania. Niemniej, w ujęciu tego myśliciela, to właśnie to zacofanie, a nie jak u Marksa, sytuacja w najlepiej rozwiniętych państwach świata, sprzyja wybuchowi rewolucji komunistycznej. Majac na uwadze Rosję, a także inne zacofane $\mathrm{kraje}^{16}$, Đilas pisze o potrzebie industrializacji jako warunku rozwoju. Industrializacji natrafiającej na przeszkody, wynikające m.in. ze słabości rodzimego kapitału oraz związanych z nim klas i partii - niezdolnych, by „skutecznie rozwiązać zagadnienie szybkiego uprzemysłowienia". Także z powodu przeciwdziałania krajów lepiej rozwiniętych, dążących do powstrzymania, zahamowania industrializacji poza swymi granicami, dostrzegających w zacofanych niepożądanych konkurentów, zagrożenie dla własnych interesów.

W rezultacie logika sytuacji musi prowadzić do powstania ugrupowania forsującego uprzemysłowienie zacofanych krajów siła, w opozycji do istniejącego ustroju. Pojawia się więc grupa, będąca „partią rewolucyjną”, „przemysłową” i ,antykapitalistyczną" zarazem. Posługuje się przemoca, terrorem, łamie bariery hamujące uprzemysłowienie i likwidację burżuazji, koniec końców - „agentury kapitału zagranicznego”. Kieruje rewolucja, „industrializacją na drodze rewolucji” w interesie proletariatu, wyrastającego „z coraz większej nędzy włościaństwa”" ${ }^{" 17}$. Osiaga założone cele, ale równocześnie przekształca się w „nową klasę”, tj. klasę „właścicieli i wyzyskiwaczy” sprawiająca, że „współczesny komunizm” jest „władzą szczególnego typu, zespalającą w sobie władanie ideami, instytucjami rządzenia oraz własnością. Innymi słowy jest on władza, która stała się celem dla samej siebie". Niemniej jego istnienie nie będzie wieczne, wraz

${ }^{16}$ Oprócz Rosji, Đilas ma na myśli Chiny i Jugosławię, gdzie również dokonała się - według niego - autentyczna rewolucja. Natomiast większość krajów Europy Środkowowschodniej, tj. Polska, Czechosłowacja, Węgry, Rumunia i Bułgaria „nie przeszły [...] przez rewolucję, gdyż system komunistyczny narzucony im został siłą Armii Czerwonej”. Tamże, s. $19-20$.

17 Tamize, s. 18-24. 
$\mathrm{z}$ „nową klasą” w rezultacie uprzemysłowienia zaczyna bowiem kiełkować nowa struktura społeczna, pojawiają się nowe warstwy społeczne, a w rezultacie - wyraźne, silne tendencje dezintegracyjne. Sprzeczne z totalitarna, monopolistyczną władzą „nowej klasy”, będą sprzyjać budowie „przyszłego społeczeństwa wolnościowego"18. Z rozważań Đilasa wynika, że o jego losie zadecyduja zmagania między tymi tendencjami i dążeniami przedstawicieli „nowej klasy”. Dawny współpracownik Tity nie ma wątpliwości co do wyniku tych zmagań. Uważa, że wolnościowe aspiracje wezmą górę, rozbijając skamieniałą strukturę totalitarnego systemu politycznego i społecznego. Zastanawia się więc głównie nad tym, jakie środki i metody okażą się najwłaściwsze i najskuteczniejsze w procesie likwidacji tego właśnie ustroju.

Przekonanie Đilasa o nieuchronnym upadku komunizmu wynika z chłodnej, wnikliwej analizy rzeczywistości. Jak pisaliśmy, w jakiejś mierze jest ona zdeterminowana, przynajmniej w tym sensie, że podlega prawom „obiektywnej konieczności”, „obiektywnego rozwoju społecznego”, niezależnie „od naszych osobistych chęci, życzeń i działań”. W rezultacie indywidualne, ludzkie wysiłki, akcje i czynności nie moga sprawić, by rzeczywistość została ukształtowana zgodnie z jakimiś finalnymi, ostatecznymi celami, by stała się absolutem, abstraktem, odpornym na oddziaływanie jakichkolwiek impulsów zewnętrznych. $\mathrm{W}$ tej perspektywie rozumowanie Đilasa jest całkowitym przeciwieństwem i zaprzeczeniem myśli, które wcześniej, w wyniku swoistej inspiracji heglizmem przedstawiali „klasycy” marksizmu-leninizmu, u schyłku zaś XX stulecia Francis Fukuyama ${ }^{19}$. Zdaniem Đilasa bowiem w żadnym wypadku nie ma czegoś, co za Fukuyamą moglibyśmy nazwać „końcem historii”; rzeczywistość nie zastyga w jakiejś końcowej i zarazem doskonałej formie. Wprost przeciwnie, charakteryzuje ją nieustanna płynność, zmiennossć, różnorodność. Co pozostaje w zgodzie ze wspomnianymi, „obiektywnymi koniecznościami”. Podobnie zreszta jak ogólny kierunek biegu wydarzeń, rozwoju rzeczywistości. W tych warunkach działalność ludzka prowadzi tylko do urzeczywistnienia konkretnych, ograniczonych i tymczasowych celów i zamierzeń. Nie narusza ogólnej zasady mówiącej,

18 Tami̇e, szczególnie s. 42, 67, 182. W przyszłości Đilas będzie ujmował istotę komunizmu identycznie. Pisząc, że „kwintesencją każdego komunizmu jest monopolistyczne rządzenie przez partię komunistyczna. W komunizmie idzie o posiadanie władzy, co więcej, władzy totalitarnej. Komunizm widzi siebie jako system całkowicie uprawniony przez bieg historii do zmian oraz kontroli nie tylko uzależnień i zachowań człowieka jako politycznej jednostki, ale również jego lektur, upodobań, wolnego czasu [...] jego całego prywatnego świata", Dżilas o Gorbaczowie. Rozmowa George'a Urbana z Milovanem Dżilasem, Warszawa 1988 (tytuł oryginalny: Djilas on Gorbachow, „Encounter”, October-November 1988), s. 4 . O przyszłym „,społeczeństwie wolnościowym”, M. Dżilas, Nowa klasa..., s. 38. Szerzej Đilas rozwinie tę kwestię w późniejszej pracy, Une societé imparfaite, passim.

19 F. Fukuyama, Koniec historii, [w:] Czy koniec historii? Konfrontacje 13, red. I. Lasota, New York-Warszawa 1991, s. 7-36. 
że niegdyśs - pisze Đilas - „celem była władza $[. . .]^{20}$. Obecnie jest nim demokracja [...]. Ale ani władza, ani demokracja nie są ostatecznymi celami. Co będzie "ostatecznym celem jutro», po [osiagnięciu - M.J.Z.] demokracji? Prawdopodobnie jej obalenie, w rezultacie dalszego [...] rozwoju. A potem? I ponownie potem? W rzeczy samej, nie ma ostatecznego celu jako konkretnego działania. To, co istnieje, to konkretny rozwój poprzez sprzeczności - nie jako cel, lecz jako koniecznośś'”21.

W rezultacie te czy inne osiagnięcia, mogące się wydawać ostatecznymi wyznacznikami określającymi naturę i charakter komunizmu, jego końcowa, niepodważalną formę, w istocie nimi nie sa. Już w końcu 1953 r. Đilas napisze, że nie należy się przywiązywać do aktualnych rozwiązań, obecnie urzeczywistnionych celów, np. „systemu kolektywizacji rolnictwa [...] starej, w istocie stalinowskiej konstytucji ${ }^{22}$ czy form organizacyjnych partii”, a nawet - jak zasugeruje - istnienia i władzy samej partii. Trzeba w nich dostrzegać tylko „mniej lub bardziej stosowne, chwilowe rozwiązania..." Osoby, które nie będą rozumiały "chwilowego i przejściowego" charakteru tych rozwiązań, tych form ustrojowych, będa przeżywać „,bolesne rozczarowania”"23, nie rozumiejąc, że „raz znalazłszy się u władzy komunizm” co prawda „zdąża ku przekształceniu reszty świata wedle swoich pojecé", ale zarazem gwałci podstawowe zasady rozwoju, coraz bardziej osłabiajac „początkowe tendencje ku przekształceniu samego siebie” ${ }^{24}$. Jego przedstawiciele nie biora pod uwagę podstawowego faktu, że system, który tworza, należy traktować identycznie jak każdą inną rzeczywistość, tj. jako ciagły, nieustanny ruch. Zmiany, jakie w nim zachodza, sa wyrazem, wynikiem urzeczywistnienia jedynie ograniczonych celów, zamysłów, zamierzeń. Nie bez racji więc w takiej interpretacji zjawisk i procesów historycznych można dostrzegać podobieństwa a nawet wpływy myśli Edwarda Bernsteina, ideologa socjaldemokracji niemieckiej, twórcy rewizjonizmu w ruchu socjalistycznym, autora słynnej tezy, że „ruch jest wszystkim - cel niczym”25.

Płynność, zmienność, różnorodność rzeczywistości... Brak możliwości określenia ostatecznego celu, końcowych, doskonałych form egzystencji ludzkiej... W rezultacie takie ujęcie musi decydować również o charakterze i możliwościach

20 „Niegdyś”, a więc w okresie okupacji i zmagań z Niemcami oraz ich sojusznikami w latach 1941-1945.

${ }^{21}$ M. Djilas, Is there a Goal? (Ima li cilja? „Borba”, 6 XII 1953), [w:] AM, s. 77.

22 Đilas ma na uwadze dwie lub jedną z dwóch konstytucji uchwalonych do $1953 \mathrm{r}$. w Jugosławii: z 31 stycznia 1946 r. lub z 13 stycznia 1953 r. (ta ostatnia była zreszta nazywana ustawą konstytucyjna), zob. M.J. Zacharias, System stalinowski w Jugosławii w latach 1944-1949, „Kwartalnik Historyczny” 1992, nr 3, s. 86-88; tenże, Komunizm, federacja, nacjonalizmy. System władzy w Jugosławii 1943-1991. Powstanie, przeksztatcenia, rozktad, Warszawa 2004, s. 145-149.

${ }^{23}$ M. Djilas, Is there a..., s. 75-79.

${ }_{24}$ M. Dżilas, Nowa klasa..., s. 7.

${ }_{25}$ Zawartej w jego pracy pt. Założenia socjalizmu, wydanej w 1899 r. 
sprawczych idei. Są one przecież częścią tej rzeczywistości. Đilas przytacza znane twierdzenia Platona o prymacie idei nad materialną rzeczywistością i przeciwstawne Marksa o dominacji tej ostatniej nad myślą ludzką. Twierdząc jednakże, że tak jak trudno sobie wyobrazić, by coś zostało zrealizowane bez wcześniejszego namysłu, pracy umysłu, tak samo „nie potrzeba setnej części intelektu Marksa”, by dostrzec, że idee nie mogą być niezależne od „społecznych i kulturowych realiów"26.

Niemniej, oba te podejścia implikują możliwość powstania „doskonałego społeczeństwa", wyrastającego z idei lub przeciwnie, materialnych przemian, warunkowanych poziomem techniki i produktywności. Rozważając te kwestie, Đilas pisze, że z czasem odrzucił oba „te skrajne, wyłączne i doktrynerskie stanowiska”, określając je mianem „przestarzałych konstruktów”. Jako ich wyraziciele, Platon i Marks błądza, snując rozważania dotyczące „ostatecznej prawdy" i uzależniając ją jednostronnie od idei lub materii. W rzeczywistości ten dychotomiczny podział, sugerujący potrzebę wyboru między „myślą i rzeczywistościa, duchem i materia, "bazą" i "nadbudową" nie znajduje uzasadnienia w świetle „dzisiejszej wiedzy” i „tęsknoty współczesnego człowieka do niepodzielności, do jedności między ludźmi oraz między nimi i naturą. Wszelkie podziały „form ludzkiej egzystencji na wyższe i niższe”, wszelkie próby rozróżnienia między „,zwierzęcymi” i „ludzkimi” aspektami bytu człowieka, „"wyrafinowanymi” i «niegodziwymi» instynktami, «duchową» i «fizyczną» aktywnością" są sztuczne, nie oddają istoty rzeczy. „Życie [...] jest podarunkiem, wartością samą w sobie (a quality of matter), siła, której nie rozumiemy i której nigdy całkowicie nie zrozumiemy”. Nie byłoby takich możliwości nawet wtedy, „kiedy bylibyśmy twórcami i osobami mogącymi zmienić je samo, jak i jego pierwotne zasady. $\mathrm{W}$ ostatecznym rozrachunku życie jest jednolite oraz różnorodne i wielorakie zarazem. Dlatego my, ludzie Zachodu, moglibyśmy znaleźć coś [...], co jest bardzo cenne we wschodnich, azjatyckich filozofiach, wyrażających głęboki, nabożny szacunek dla wszystkich form i przejawów życia”².

Musimy jednakże stwierdzić, że sugerując potrzebę integralnego ujmowania wszystkich aspektów ludzkiej egzystencji, Đilas nie zawsze i nie do końca jest konsekwentny. Głównie dlatego, że często pisze przede wszystkim o ideach, zwłaszcza w swoich późniejszych dziełach ${ }^{28}$. Zaznacza, że niezależnie od swej marksistowskiej indoktrynacji pozostawał pod wpływem „oczywistego faktu”, że to właśnie idee kształtują politykę, społeczeństwa, wpływają na charakter dzieł sztuki. Jak zobaczymy w swoisty, ściśle ograniczony sposób, co trzeba podkreślić. Więzienne przemyślenia ${ }^{29}$ utwierdziły go w przekona-

${ }^{26}$ M. Djilas, Of Prisons and Ideas..., s. 47-48.

${ }_{27}$ Tamże, s. 47-49.

${ }^{28}$ Mam na myśli przede wszystkim ostatnio cytowaną pracę.

${ }^{29}$ W Królestwie Jugosławii w latach 1933-1936 i w komunistycznej Jugosławii dwukrotnie, w latach 1956-1961 oraz 1962-1966. 
niu o znaczeniu idei. Głównie dlatego, że „jak pustynia - pisze metaforycznie i nieco poetycko - więzienie sprzyja przeżywaniu idealnego świata, świata idei jako świata rzeczywistego" ${ }^{30}$. Dodaje, że idee powstają w ludzkich głowach, umysłach, choć w powiązaniu z faktycznymi warunkami życia oraz „duchową spuścizną" społeczeństw i narodów. Z tym tylko, że na początku mamy do czynienia z niejasnymi, nieokreślonymi myślami, stającymi się ideami dopiero w rezultacie swoistej „idealizacji”, tj. „umysłowej interpretacji realnego świata” - jego przeszłości, teraźniejszości i przyszłości, a więc rzeczywistości traktowanej całościowo. Właśnie wtedy pojawiaja się idee, w „ „doskonałej», absolutnej formie” w zgodzie z ludzką inklinacja „do prawdy, do absolutu”. Nie jesteśmy w stanie przewidzieć, jakie będą wyniki praktycznego urzeczywistnienia tych idei, szczególnie politycznych, kształtujących stosunki międzyludzkie. Mogą one być różne, ponieważ „wszelkie dobro, ale i każde zło wyrasta [...] w ludzkich umysłach". W tych warunkach idee należy traktować ostrożnie. Nawet zakładając, że są one „największa, twórczą potrzebą człowieka" ${ }^{11}$.

Można zauważyć, że to właśnie skłonności „umysłów ludzkich” do zła, ułomności natury ludzkiej, skłaniały Đilasa do wyrażania wątpliwości nie tylko w pozytywną jedynie moc sprawczą idei, ale i szerzej - do stawiania pytań, czy te idee w ogóle mogą wpływać na działania różnych rządów, narodów i społeczeństw. Takie pytania były w jakiejś mierze sprzeczne $\mathrm{z}$ wyżej przedstawiona ocena autora Nowej klasy o przynajmniej ograniczonym wpływie idei na rzeczywistość. Tę niekonsekwencję dostrzegamy w jego refleksjach w związku z wydarzeniami w Jugosławii w czasie II wojny światowej. Đilas pisze, że wedle jego przewidywań tamtejsza „rewolucja i wojna domowa” miała wynikać z ideologicznego konfliktu dwóch klas, tj. „burżuazji i proletariatu”; miała być walką „W miastach i wielkich centrach". Tymczasem stopniowo przekształcała się w krwawe konflikty „na wsiach, przeważnie między ludźmi pracy, często między sassiadami i bliskimi krewnymi”. Niekiedy przybierała tak wielkie rozmiary, że wypierała i przyćmiewała walkę z okupantami. W rezultacie „projektowana konfrontacja ideologiczna, podobnie jak ideologiczna motywacja, bladła i ulegała wypaczeniu”. „Co to za ideologia - pyta Đilas - co to za marksizm, który zamiast konfliktu z burżuazją i wyzyskiwaczami prowadzi do walki z drobnomieszczaństwem, podrzędnymi urzędnikami i chłopami”. A także, „co to za Serbowie i nacjonaliści, którzy przyjmują uzbrojenie od okupanta, pozostaja na jego garnuszku i uczestniczą w jego akcjach wojennych" ${ }^{22}$. Ponadto, ,jaka siła sprawia, że ludzie się zabijają”. Nie może nią być ideologia, choćby nazistowska, „uproszczona i antyhumanitarna”. Podobnie jak niemiecka „dyscyplina państwowa”, nie może ona zmusić „profesorów z Heidelbergu i potomków hanzeatyckich

\footnotetext{
${ }^{30}$ Tamże, s. 48.

${ }^{31}$ Tamże, s. 14-15.

${ }^{32}$ M. Đilas, Razvoj..., cz. 7.
} 
patrycjuszy do uganiania się po czarnogórskich i bośniackich bezdrożach, by zabijać pastuchów i studentów [...], a także Żydów w całej Europie”. Jeśli więc „nie nazistowska” ani „nie nasza, komunistyczna ideologia” jest przyczyną mordów, gwałtów i bestialstw, to musi za nimi stać jakaś „niewytłumaczalna siła”. Ideolodzy, politycy, przywódcy państwowi „wyczuwaja ja” w ludziach i narodach oraz wykorzystuja do urzeczywistnienia swoich „podniosłych celów”. To właśnie to „coś” - nieokreślone i niewyjaśnione, a nie ideologia - „u nas i u nich” - ma zasadnicze znaczenie. „Na swój sposób” można je przedstawić posługując się jedynie ,artystycznymi inspiracjami, mistycznymi uniesieniami wiernych” oraz wykorzystując „domysły filozofów” [podkr. M.Đ.] ${ }^{33}$.

Pomijając te ostatnie, poetyckie i niejasne metafory i określenia, należałoby tylko stwierdzić, że w takim ujęciu każda ideologia staje się czymś wtórnym w stosunku do pierwotnych, ludzkich instynktów i namiętności. A także czymś sprzecznym z rzeczywistościa, która najczęściej rozwija się w zgodzie właśnie z nimi i własną logika. W rezultacie ideologia tylko w pewnym stopniu, w ograniczonych rozmiarach może służyć urzeczywistnianiu tych czy innych celów i zamierzeń - społecznych, politycznych, ustrojowych.

Powyższe poglądy zostały przedstawione dopiero w latach 70. i 80. XX stulecia. Nie wiemy więc, czy wiernie oddają bieg myśli Đilasa w czasie wojny, czy też są tylko projekcją wstecz jego późniejszych, powojennych przemyśleń. Tak czy inaczej zostały one wyrażone, łącznie z ocena, że idee w żadnym wypadku „nie moga kształtować lub zmieniać rzeczywistości zgodnie z wyobrażeniami ich wyrazicieli”. Niezależnie od faktu - pisze Đilas - że są one ściśle powiązane z rzeczywistościa, że są częścią tej samej, określonej całości. Natura i ograniczone „moce” idei sprawiaja, że wszelkie wysiłki dostosowania do nich rzeczywistości muszą ponieść fiasko. Idee mogą tylko inspirować proces „zmian” postulowany przez „rewolucjonistów” lub próby i programy utrzymania status quo, przedstawiane przez „konserwatywnych filozofów”. Każda idea jest wyłącznie „pochodnią oświetlająca drogę [...] przez dżunglę niegościnnej i nieprzeniknionej rzeczywistości”. To, że w umysłach swych „orędowników” i „męczenników” jawi się ,jako coś doskonałego - ostatecznego i niezawodnego" - nie ma żadnego znaczenia ${ }^{34}$.

Zdaniem Đilasa po zwycięstwie, po dojściu do władzy nosicieli określonych idei zawsze pojawiają się nowe formy rzeczywistości. Stopniowo eliminuja głoszone idee, ale nie mogą zapobiec, by na gruzach starych nie powstawały nowe. „Wieczny, święty ogień nigdy [...] nie wygasa”. Nawet wtedy, kiedy zwycięzcy wytężaja wszystkie siły, by uniemożliwić, by zdusić narodziny kolejnych idei. Będą one powstawać do końca istnienia „rodzaju ludzkiego”. Jest to wieczny, nieustający proces, w którym idee rodzą się tylko po to, by ulec zniszczeniu i natychmiast powstać ponownie. Niszczy je nowy porządek, wprowadzając mechanizmy,

${ }^{33}$ Tamże, cz. 7; M. Djilas, Wartime..., s. 285; tenże, Of Prisons and Ideas..., s. 11-12.

${ }^{34}$ M. Djilas, Of Prisons and Ideas..., s. 51. 
które burzą stary, a zarazem idee, uzasadniające ten proces niszczenia. Przejście od idei do nowego porządku jest tragiczne dla ich wyznawców oraz rujnujące, jałowe i demoralizujące dla tych, którzy nie pojęli, a tym bardziej - nie stali się zwolennikami nowej rzeczywistości. „Rewolucjoniści, których nie pochłonęła rewolucja pożerają się wzajemnie. Nowe zaś generacje pogrążają się w apatii, narkotycznym otępieniu i nienasyconym hedonizmie". Do czasu, niezależnie bowiem od tego ponurego, przygnębiającego stanu, „niematerialne i niematerializujące się idee” występują ponownie, nieustannie się pojawiają - „odmłodzone”, skłaniające do podejmowania kolejnych prób kształtowania rzeczywistości. Przynajmniej tak długo, jak istnieją ludzie, którzy „w nie wierzą i są skłonni poświęcić się dla nich”. Mając na uwadze własne doświadczenia Đilas pisze, że pobyty w więzieniu oraz idee, traktowane jako „wiara w możliwości wprowadzenia jeśli nie doskonałego, to przynajmniej ulepszonego świata”, w pewnym sensie „zwodzą” więźnia - „wyznawcę [idei - M.J.Z.]”, bo pogłębiają jego przekonania dotyczące potrzeby może nie całkowitej, ale więcej niż ograniczonej zmiany rzeczywistości. Jak wynika z logiki myśli autora Nowej klasy - zupełnie nieuzasadnione, powiększające jednakże grono tych, którzy wystawiają się na ryzyko w imię wzniosłych, szlachetnych idei ${ }^{35}$.

Đilas rozumie i z sympatią odnosi się do idealistycznych pobudek działania tych czy innych wywrotowców, buntowników, rewolucjonistów. Niemniej wyraźnie daje do zrozumienia, że podobnie jak sama rzeczywistość, również idee, będące wszakże częścią rzeczywistości, charakteryzują się płynnościa, zmiennościa, różnorodnościa, a niezależnie od tego - podatnością na załamania w zetknięciu z postulowanym, doskonałym porządkiem - społecznym czy politycznym. W rezultacie nie ma możliwości naprawy, uzdrowienia rzeczywistości za pomocą z góry ustalonego planu, określonej idei czy szerzej - ideologii, wyznaczajaccej ostateczne, absolutne cele, kształtującej idealne i niezmienne ramy, instytucjonalne rozwiązania dla danej społeczności, narodu, państwa. Szczególnie wtedy, kiedy „doskonałe społeczeństwo” miałoby powstawać z wykorzystaniem brutalnych, bezwzględnych środków, przy użyciu siły, przemocy, terroru. Prowadziłoby to do naruszenia równowagi, która winna występować między ideami, środkami i działaniami. Równowagi potrzebnej do właściwego funkcjonowania każdego społeczeństwa. Już w 1953 r. Đilas napisze, że nieodpowiednie środki mogą doprowadzić do wypaczenia najwznioślejszych idei, zgodnie z powiedzeniem, że „dobrymi chęciami wybrukowana jest nawet droga do piekła" ${ }^{36}$. W rezultacie z pewna ambiwalencja potraktuje ruchy kontestacyjne u schyłku lat 60 . XX stulecia. Z jednej strony wykaże pewne dla nich zrozumienie piszacc, że „szarzyzna dobrobytu, traktowanego jako najwyższy ideał”, a także kapitalistyczne społeczeństwa przemysłowe „bez duszy, myślące tylko

\footnotetext{
${ }_{35}$ Tamże, s. 51-52.

${ }^{36}$ M. Djilas, Concretly, [w:] AM, s. 94.
} 
o zysku”, musiały „wzbudzać niezadowolenie i urazy tzw. grup goszystowskich”. $\mathrm{Z}$ drugiej jednakże dostrzega niebezpieczne, fanatyczne tendencje i zamierzenia studenckich przywódców, m.in. Daniela Cohn-Bendita i Rudi Dutschkego czy szerzej - przedstawicieli zachodniej Nowej Lewicy, którzy za fasadą wzniosłych i szlachetnych idei ukrywają chęć zdominowania społeczeństwa, a także „gwałtowne metody”, mające służyć „urzeczywistnieniu ideologii”, a więc - naruszeniu wspomnianej równowagi między ideami, środkami i działaniami ${ }^{37}$. Zdaniem Đilasa tylko ona może zapobiec degeneracji idei, głównie dzięki powściągliwemu użyciu środków i umiarkowaniu w doborze celów, wspieranych przez idee oraz ideologie. „Sedno [...] mojego konfliktu z partią tkwiło właśnie w tym, że zrozumiałem, iż same idee nie czynią ludzi ani złymi, ani wzniosłymi. Jedynie środki, które są używane sprawiaja, że ludzie stają się jednymi albo drugimi” ${ }^{38}$. Niewłaściwie dobrane, tj. uwzględniające głównie nagą siłę i przemoc powoduja, że każda próba pozytywnego przekształcenia społeczeństwa staje się zajęciem niewykonalnym, jałowym, utopijnym. To właśnie przytrafiło się Leninowi i bolszewikom w 1917 r. i później.

Zdaniem Đilasa „deformacje” sowieckiego systemu wynikają z istoty rzeczy. Opierają się na błędnym przekonaniu o możliwości urzeczywistnienia „utopii”, na teorii fałszującej rzeczywistość oraz „amoralnym” potraktowaniu idei, tj. na założeniu, że cele uświęcają środki, w tym wypadku - że „wszystko, co służy "proletariatowi» jest tym samym moralne". W rezultacie szczytne i szlachetne cele - elementy utopii, są podporządkowywane i eliminowane przez tych, którzy posługując się przemoca mieli je realizować. „Utopijna idea”, a więc „«naukowy dogmat» o bezklasowym społeczeństwie" zostaje przez komunistyczną oligarchię zburzony, staje się jedynie „opium dla mas”, służacym umocnieniu jej władzy. W czasie rządów Stalina „ideologie, utopia” sa już tylko „środkami”, natomiast jego partyjni oponenci, „w mniejszym lub większym stopniu wyznawcy utopii”, traca życie w toku walki o władzę. To instrumentalne potraktowanie ideologii nie przeszkadza Stalinowi być „ostatnim, wielkim utopistą «naukowym»”. W miarę wzrostu brutalnej władzy i przywilejów „kierowniczej warstwy” odkrywa on drogę do "«wykorzenienia pozostałości klasowej mentalności» i «budowy bezklasowego społeczeństwa»”. „Naukowy socjalizm” ma umacniać władzę Stalina, a także jego następców - sprawowaną w kraju i za granica, dzięki ekspansji. Niezależnie od faktu, że taki „socjalizm”, „praktykowany przez współczesny komunizm”, przestaje wyrażać wspólną, „monolityczną ideę międzynarodową” i prowadzi do powstania „masy państw, posiadających interesy, często - całkowicie sprzeczne”. A także społeczeństw rządzonych przez „nową klasę” oraz do wojen między komunistycznymi państwami. Obecnie są one nieuniknione. W rezultacie „fetor idei w rozkładzie [...] ogarnia całą ziemię”. Słabnąca idea

${ }^{37}$ M. Djilas, Une societé imparfaite..., s. 258-261.

38 Tamize, s. 277. 
staje się „wstępem, jeśli nie warunkiem [? - M.J.Z.] ekspansji siły”. Powstał i nadal powstaje łańcuch państw pod hegemonią sowiecka. Już w czasie rządów Stalina oligarchia w ZSRR „przekształciła się nie tylko w więźnia własnej idei ${ }^{39}$, lecz także dusiciela ludzkich i narodowych wartości”"

Czy taki system może przetrwać? Đilas stwierdza, że „osobiście” nie wierzy, by „sowiecki [...] mógł się przekształcić w swobodniejsze społeczeństwo, pozbawione zaborczych zapędów [...], przynajmniej w przyszłości, która da się przewidzieć" $^{41}$. W innym jednakże miejscu zdecydowanie podkreśla tezę o kryzysie współczesnego mu komunizmu. Jego sądy w tej sprawie są poniekąd zaskakujące, pozornie niespodziewane, wiążą się bowiem z akceptacją i podkreśleniem pozytywnej roli różnych utopii. Dotychczas przedstawione opinie pozwalałyby przecież sądzić, że autor Nowej klasy traktuje je tylko jako przeszkody, hamujące właściwy rozwój społeczeństw. Tymczasem pisze, że „obecnie komunizm jest pograżony w kryzysie”, właśnie dlatego, że nie jest już utopijny, „nawet w tym stopniu jak niegdyś". Nie wierzą weń nie tylko robotnicy, ale nawet przedstawiciele „rządzącej, uprzywilejowanej klasy. Wraz z zanikiem [...] utopijnej wiary, komunizm stracił swą duszę, swą raison d'être [...], rewolucyjną moc, swą wulkaniczną siłę". Jego istota jest już tylko żądza władzy, prowadząca niechybnie do „jego destrukcji”" ${ }^{2}$. Komunizm nie jest żadna „utopią u władzy”, wbrew temu co podkreślaja - dodajmy od siebie - niektórzy badacze tego systemu ${ }^{43}$. Przeciwnie, jest porządkiem, ustrojem, który burzy swoja początkowa, utopijną wiarę, nie dopuszczając zarazem, by jej miejsce mogły zająć jakieś nowe, utopijne wizje rzeczywistości. W rezultacie pozbawia się warunków, zapewniających możliwości przetrwania. „Zachodnie” społeczeństwa - szczególnie północnoamerykańskie, są stabilniejsze od „wschodnich”, komunistycznych. Głównie dlatego, że opierają się na utopii, na wierze, że „ludzie rodzą się wolni, że Bóg obdarzył człowieka wolnością i wolną wolą"44.

Zdaniem Đilasa „utopijne projekty”, zamysły wprowadzenia „doskonałego społeczeństwa” występują „we wszystkich cywilizacjach”. Przede wszystkim dlatego, że nikomu nie udało się dotąd stworzyć społeczeństwa tak dobrze zorganizowanego i funkcjonującego, by u kogokolwiek nie pojawiły się tęsknoty do utworzenia jeszcze lepszego. „W tzw. cywilizacji zachodniej” są one widoczne niemalże od jej zarania: w judaistycznych poszukiwaniach Ziemi Obiecanej,

${ }^{39}$ Mając na uwadze twierdzenie Đilasa o zniszczeniu przez stalinowską biurokrację „utopijnej idei”, można by powiedzieć, że takie określenie zdradza pewną niekonsekwencję autora Nowej klasy.

${ }^{40}$ M. Djilas, Of Prisons and Ideas..., s. 62 i n., passim.

${ }^{41}$ Tamże, s. 63.

${ }^{42}$ Tamże, s. 54.

${ }^{43}$ Mam tu na myśli m.in. pracę M. Heller, A. Niekricz, Utopia u władzy. Historia Zwiazku Sowieckiego, t. 1 i 2, Wrocław 1989.

${ }^{44}$ M. Djilas, Of Prisons and Ideas..., s. 54-55. 
filozofii Platona, dążeniach wspólnot wczesnochrześcijańskich, a w czasach późniejszych - w różnych systemach filozoficznych, zmierzajacych do „zracjonalizowania” ludzkiej egzystencji. W istocie „zachodnia gleba kulturowa niezaprzeczalnie najbardziej obfituje we wszelkiego rodzaju utopie". Także komunistyczne. Dla ich wyznawców „nędza i niesprawiedliwość” stają się główną motywacją działań podejmowanych z myślą o „eliminacji cierpienia, jakie życie zbytecznie przynosi" ludziom. To właśnie utopijne, komunistyczne działania, jak i „współczesny komunizm są starsze od sowieckiego porządku” ${ }^{\text {”5 }}$. Ich korzeni należy poszukiwać w judaizmie i chrześcijaństwie, w starożytnej filozofii, a także - pisze Đilas - „w ogóle u zarania ludzkiej historii”. Co więcej, swoiste, widoczne dążenia do stworzenia doskonałej rzeczywistości można dostrzec także wśród „antykomunistów”; u nazistów, występujących z wizja „wyższej rasy” i robiących wszystko, by doprowadzić do powstania „«czystych» Aryjczyków”. Z drugiej strony - u „demokratów” występujących z ideami ,wolnego człowieka” i „wolnego społeczeństwa", które można potraktować jako utopie, jeśli staną się one podstawą wysiłków utworzenia idealnych, absolutnych bytów ${ }^{46}$.

Wszystkie te przykłady prowadzą Đilasa do wniosku, że „idea utopii” motywuje ludzkie działania. „Podobnie jak egzystencję człowieka poza wspólnota można sobie tylko wyobrazić, tak samo można sobie jedynie wyobrazić wspólnotę na tyle doskonała, by nie powstawały w niej utopie przynoszące nadzieję i równoważące” cierpienia wynikające z rzeczywistych warunków życia. „Utopia jest rodzajem religii”. Ich eliminacja musiałaby oznaczać pozbawienie człowieka i społeczeństwa zasadniczej, niezbędnej „motywacji duchowej do życia” ${ }^{47}$.

Ostatecznie rozważania Đilasa prowadzą do wniosku, że nie należy i nie można wyplenić utopii z ludzkich umysłów. Byłoby to szkodliwe i niemożliwe zarazem. Chodziłoby tylko o to, by pozbawiona „absolutystycznych” dążeń idea, utopia istotnie mogła być przydatna. Potraktowana jako dążenie do urzeczywistnienia „ostatecznego celu”, do wprowadzenia „doskonałego społeczeństwa”, utopia niechybnie stanie się narzędziem służącym narzuceniu i umocnieniu tej czy innej władzy, w miarę upływu czasu ulegając powolnemu, stopniowemu niszczeniu, w wyniku walki różnych frakcji i komasacji władzy przez jedną z nich, w rezultacie posługiwania się przez nie gwałtem, przemoca, nagą siła. Đilas wyraźnie pozostaje pod wpływem doświadczeń związanych ze zdobyciem władzy przez komunistów w Rosji, Chinach, Jugosławii i w innych krajach środkowoeuropejskich. Nie mając przy tym wątpliwości, że podobnie jak początkowo komunistyczna, wszystkie utopie, identycznie jak „wszystkie religie muszą być totalne”, jeśli mają wystapić w roli „jedynie prawdziwych”, jeśli maja „oświecać i oferować rozwiązania zasadniczych problemów egzystencjalnych". W przeciwnym razie „nie byłoby powodu, by w nie wierzyć”.

\footnotetext{
${ }^{45}$ Tamże, s. $57-61$.

46 Tamize, s. 58.

${ }_{47}$ Tami்e, s. 59 .
} 
Taka ocena mogłaby skłaniać do pesymizmu. Do wniosku, że utopie jedynie pozornie mogą być przydatne. Niemniej totalna natura utopii nie oznacza, że zarazem muszą one być totalitarne. Stanowiąc w istocie zamknięte, totalne systemy, pretendujące do wyjaśnienia i - jak można by stwierdzić - „uzdrowienia" wszystkich aspektów egzystencji, utopie nie muszą być totalitarne. Co oznacza, że nie muszą być systemami, które „wykluczają lub zabraniają wyrażać, głosić inne idee, inne utopie". By się o tym przekonać wystarczy porównać " "Zachodnie» i «wschodnie» systemy". Zarówno jedne i drugie wyrażają różne utopie. Niemniej tylko te ostatnie, czyli „wschodnie”, komunistyczne powstały na bazie utopii totalitarnych ${ }^{48}$.

Đilas sugeruje, że długofalowe utrzymywanie totalitarnego charakteru utopii jest niemożliwe. Przede wszystkim dlatego, że idee i utopie eliminujące inne niechybnie prowadzą „w ślepą uliczkę”, do stagnacji i upadku, do konfliktu z rzeczywistymi celami i dążeniami jednostek oraz społeczeństw. Nie moga więc całkowicie i bez końca panować, nie moga zachować prawa do wyłączności, nawet gdy uzyskuja, jak w średniowieczu, ,niemalże powszechne władanie nad duszami”, pozwalające niszczyć „sekty heretyków” oraz wszelkie krytyczne, racjonalne myślenie. Bieg życia, zmienna rzeczywistość prowadzą również do tego, że choć „z natury totalne”, idee i utopie muszą ulegać ewolucji, niejako same w sobie; „, nie moga być totalne bez utraty, bez zdeprecjonowania własnej tożsamości". Z niezbyt jasnego i precyzyjnego sposobu wywodu Đilasa w tym miejscu można by wnioskować, że w toku przemian, tj. pojawienia się nowych okoliczności i uwarunkowań, totalne idee także ulegają ewolucji, nie przestając jednakże nadal być totalnymi. Ich wyznawcy utrzymują dążenia do przedstawiania ,jedynie prawdziwego" rzekomo charakteru rzeczywistości i środków służących rozwiązaniu różnorodnych problemów. Z tym tylko, że w poszczególnych momentach płynnej rzeczywistości nieco inaczej lub po prostu inaczej przedstawiają treść swej „prawdy”, zmieniając czasami również niektóre jej elementy. Đilas o tym nie pisze, ale dobrym przykładem takiego traktowania utopii mogłyby być różne nurty i wyznania chrześcijańskie. W rozumieniu autora Nowej klasy nie zmienia to faktu, że utopia nadal jest zjawiskiem totalnym, dostosowanym jedynie do zmienionej rzeczywistości. Głównie dlatego, że dotychczasowa, w starej formie czy treści, byłaby „obca utopia”, przynosząca - jak się wyraża - „nieszczęście życiu”. Najtrwalsze i najbliższe naturze człowieka są te utopie, których twórcy wierzą „w swoją słuszność i prawdę”, ale równocześnie godzą się z istnieniem ,innych idei, tendencji oraz form”. Najdoskonalszą zaś jest zawsze utopia, w której odnajdujemy świadomość własnej „niedoskonałości” oraz otwartość „na krytykę”, a nawet „odrzucenie” ${ }^{49}$.

Z wywodu Đilasa nie dowiadujemy się, czy i w jaki sposób można by pogodzić wiarę we „własną słuszność i prawdę” z przekonaniem o „niedoskonałości”

${ }^{48}$ Tamże, s. 59-61.

${ }_{49}$ Tamże, s. 61. 
własnej utopii. Wydaje się, że w takim ujęciu kryją się pewne sprzeczności. Jednakże niezależnie od tego, bardzo istotna jest jego konstatacja, że przezwyciężenie przestarzałych idei, utopii nie może nastapić na drodze zakazu czy nakazu. To byłoby „bezsensowne i beznadziejne”. Jedyną droga jest „walka idei”, przedstawienie „racjonalniejszych, żywotniejszych [...],«bardziej utopijnych utopii»”, a więc takich, które lepiej służą społeczeństwom w zmieniającej się rzeczywistości. Nic więc dziwnego, że dostrzegając potrzebę „przekształcenia obecnych, biurokratycznych systemów” i „stworzenia wolnego, otwartego społeczeństwa”, Đilas wiąze tę „czysta, utopijną utopię" z postulatem odrzucenia zamkniętej, skostniałej teraźniejszości marksistowsko-leninowskiej w ZSRS i innych krajach „socjalistycznych” ${ }^{\circ 0}$. Jak sugeruje - teraźniejszości pretendującej do tego, by stać się uniwersalną wizją przyszłości. Jego zdaniem nowa, „czysta, utopijna utopia" stałaby się w istocie intelektualną podstawa przejścia od totalitaryzmu do demokracji. Z widoczną myśla, że z czasem byłaby ona zastępowana przez inne, jeszcze lepiej wyrażające płynna, zmienną rzeczywistość i potrzeby, które będa w niej powstawać. W rezultacie utopie sa potrzebne, ale jedynie jako nośniki, jako stymulatory niezbędnego rozwoju. Nie może to budzić zdziwienia, bo w istocie są one rozwiniętymi, można by powiedzieć, idąc za myślą Đilasa - pogłębionymi, finezyjnie przedstawianymi ideami, zestawami idei. Podobnie jak one, sa tylko inspiracja, „pochodnią” umożliwiającą drogę rozwoju rzeczywistości - niedoskonałej z istoty, a więc - nie zastygającej w jakiejś określonej, perfekcyjnej treści i formie. W tych warunkach świat, aby się rozwijać, koniecznie musi być utopijny - ale tylko w tym znaczeniu, jakie sugeruje Đilas. Swobodne idee, utopie, są główną przesłanką rozwoju. Mają zdolność stopniowego przekształcania i ulepszania rzeczywistości. W odróżnieniu od idealnych, „doskonałych” postulatów, niemożliwych w praktyce i przekształcających się w swoje przeciwieństwa, zgodnie z prawami dialektyki. Jak w systemach komunistycznych, w których władza ludu staje się władzą partyjnej oligarchii, własność społeczna - biurokratyczna, społeczeństwo bezklasowe, społeczeństwem rządzonym przez „nową klasę"; jak w zbiorowościach, w których więzienia i zakazy zastępują wolność, braterstwo zamienia się „w bezlitosne regulowanie sekciarskich porachunków”, równość - w dominację najsilniejszych, pokój - „w wojny między komunistycznymi państwami itp., itd." ${ }^{\circ 1}$.

Ostatecznie, skoro idee oraz utopie nie moga zapewnić powstania „doskonałego społeczeństwa", radykalne środki, po które sięgaja jego zwolennicy, mogą zaś prowadzić, a najczęściej - niechybnie prowadza - do gwałtów, mordów i przemocy, a w końcu do zniewolenia, to metody rewolucyjne muszą zostać wykluczone, także wtedy, gdy chodzi o wyjście z komunizmu, tym bardziej że spełniwszy swoją misję, tj. industrializację i urbanizację u „zacofanych”, sys-

\footnotetext{
50 Tamże, s. 57-61.

51 Tami̇e, s. 150 .
} 
tem komunistyczny czy też systemy komunistyczne stają się podatne na wszelkie przemiany. W ich łonie pojawiają się różnorodne procesy dezintegracji i dywersyfikacji. Mając na uwadze, jak ocenia, wyraźne podobieństwa tych systemów z różnymi wyznaniami, Đilas pisze, że na początku były one tylko „ideologiami” o wyraźnych „znamionach religii”. Mogły, a nawet musiały, mieć „określone centrum”. Jednakże w chwili, kiedy „idea” została ucieleśniona w postaci „różnych państw” zaczęły się ujawniać odmienne „interpretacje dogmatu”, jak w czasie reformacji, gdy „książęta” zaczęli się przeciwstawiać władzy papieży. W rezultacie w komunizmie pojawia się „stała tendencja do emancypacji narodowej oraz różnorodności ideologicznej” zarówno w poszczególnych krajach, jak i między nimi. W tym ostatnim przypadku chodzi głównie „o coraz głębszy konflikt dwóch supermocarstw - Zwiazku Sowieckiego i Chin". Idea internacjonalistyczna jest tu coraz bardziej wypierana przez idee oraz dążenia narodowe ${ }^{52}$.

Sugerując możliwości powstania systemu wolnościowego, Đilas pisze, że w społeczeństwach komunistycznych powstają nowe warstwy, grupy o zróżnicowanych celach oraz ideach, coraz bardziej odbiegające od początkowej, komunistycznej „wiary”, ortodoksji. Nie potrzebuja one ani „idealnego społeczeństwa”, postulowanego przez partyjnych ortodoksów, propagandystów czy ideologów, ani totalitarnej ideologii. A także „uścisku rządu i ekonomii, obu w rękach zideologizowanej grupy utrzymującej monopolistyczną władzę" ${ }^{33}$. Đilas ma na myśli osoby pochodzące z różnych środowisk, „od szczytów samej oligarchii partyjnej po wykwalifikowanych robotników i zasobnych wieśniaków”. A także specjalistów: „artystów, inżynierów, profesorów, techników, dyrektorów”. Wspólnie tworzą oni „szczególnego rodzaju klasę średnią”, niezainteresowana, a nawet przeciwną ,jakiejkolwiek doktrynie”, dążąca do podniesienia poziomu życia, uzyskania rentownych zawodów, powstania nowoczesnych technologii. Ta „klasa średnia” powstaje spontanicznie w wyniku industrializacji i dzięki stosunkom stwarzanym przez "technologię przemysłową”. Obecnie nie ma struktur organizacyjnych ani własnej ideologii. Niemniej zaczynaja się w niej pojawiać teoretycy, głoszący niezależne idee i wyrażajacy sympatię dla systemu demokratycznego. Partyjna biurokracja nie może ich unicestwić, ponieważ nie mogłaby „utrzymać się przy władzy bez postępu technicznego" ${ }^{\text {"5. }}$. $\mathrm{W}$ rezultacie musi ich tolerować, a nawet iść wobec nich na pewne ustępstwa. Niezależnie od tego, że przedstawiciele „klasy średniej” krytycznie oceniaja niewydolność systemu, rozbijaja jego średniowieczne, feudalne w istocie struktury, utrudniajace czy wręcz uniemożliwiajace modernizację gospodarki55. Pisząc o pewnych precedensach, Đilas ma nadzieję, że „w systemach komunistycznych” pojawią się „różnorodne struktury własności”, także prywatnej.

\footnotetext{
52 M. Djilas, Une societé imparfaite..., s. 224-225.

53 Tamże, s. 284-286.

54 Tamże, s. 226-228.

55 Tamże, s. 213, 247-248.
} 
„Pozbawiona wreszcie pasożytów politycznych i biurokratycznego zarządu, każda własność socjalistyczna będzie musiała się zmieniać, ulepszając swe struktury i metody zarządzania, dostosowując się do wymogów nowoczesnej technologii i światowego rynku". Będzie to wymagało usprawiedliwienia i uzasadnienia „budowy i rozwoju prywatnego przedsiębiorstwa”, ale z tym nie powinno być trudności, przynajmniej w przypadku Jugosławii. Đilas twierdzi, że tamtejsi komuniści wykazują się dostateczną wyobraźnią i pragmatyzmem, głównie zaś niebywałymi umiejętnościami czerpania z „arsenału dogmatów” różnych „racji: "socjalistycznych» i "marksistowskich»", by usprawiedliwić takie posunięcia. W rezultacie prywatne przedsiębiorstwa będą powstawać, choć „pod warunkiem, że nowi właściciele" nie zagrożą władzy komunistów ${ }^{56}$.

Wraz z ewolucją społeczną taka sytuacja będzie stwarzać warunki stopniowego zanikania komunizmu i powstawania „systemu wolnościowego”, tym bardziej że w rezultacie nieuchronnego rozwoju społecznego i konieczności ekonomicznych, sami funkcjonariusze partyjni staną się osobistościami, które pod wpływem tendencji pragmatycznych i doktrynerskich, przemiennie występujących w ich polityce, będa ,grabarzami” systemu. Mając na uwadze przypadek Jugosławii i polityki Tity, Đilas pisze, że „w czasie życia jednej generacji ci sami przywódcy przekształcali się z rewolucjonistów w despotów, z despotów w «liberałów», posługując się ideałami komunistycznymi jedynie jak marka fabryczna" ${ }^{\text {"57 }}$, w celu utrzymania władzy. Te ciagłe zmiany, „triki ideologiczne”, w powiązaniu ,z głupim przeciwdziałaniem” koniecznościom, stwarzanym „przez życie” uczyniły z komunizmu - „niegdyś nadziei i przewodnika rzesz ludzkich” „jakąś obrzydliwą mieszankę”. „Obrzydliwa”, ale podatną na obce „burżuazyjne” wpływy, zachodni styl życia, „podmywającą" zasady i fundamenty komunizmu, a przez to - wspierająca wspomnianą dezintegrację systemu ${ }^{58}$.

Đilas uważa, że komunizm jest skazany na zagładę i w rezultacie w Społeczeństwie niedoskonatym pisze jedynie o drogach, które mogą do tego prowadzić. Odrzuca środki siłowe, rewolucyjne nie tylko dlatego, że nie wierzy w możliwości ostatecznych, „zbawczych” celów osiaganych za ich pomoca, ale i z przekonania, że rewolucyjne metody, niezależnie od tego, że gwarantują jedynie gwałty

\section{Tamże, s. 213-214.}

57 Tamize, s. 221.

${ }^{58}$ Tami்e, s. 221-223. Na marginesie: wydaje się, że zupełnie nieświadomie Đilas wybiegł w tym miejscu zbyt daleko w przyszłość. Jego rozważania są tu bardziej wytworem wyobraźni, antycypującej przyszłe wydarzenia - i to nie w Europie, lecz w Azji - niż analizą ówczesnej sytuacji w krajach bloku sowieckiego, a także we względnie liberalnej Jugosławii lat 60. XX w. Nawet wówczas bowiem Tito i jego przyjaciele nie przypominali Deng Xiaopinga i jego zwolenników w Chińskiej Republice Ludowej na przełomie XX i XXI w. Reformy Tity, także gospodarcze, miały ograniczony charakter i na początku lat 70. załamały się w związku z obawą utraty władzy przez SKJ i rozpadu państwa, zob. M.J. Zacharias, Komunizm, federacja, nacjonalizmy..., s. 277 i n. 
i zniewolenie, sa po prostu zbędne. Dezintegracja i dyferencjacja systemów komunistycznych prowadzi go do wniosku, że wystarczą takie metody walki, jak manifestacje, demonstracje, marsze protestacyjne, rezolucje różnych osobistości, przywódców tych czy innych ugrupowań, „odważna krytyka i spoistość moralna”; pisze, że „dzisiejsze społeczeństwa rządzone przez komunistów nie potrzebuja rewolucji, lecz ruchów reformistycznych oraz demokratycznych przekształceń" ${ }^{59}$. Pojawienie się kolejnych rys na systemie komunistycznym, a więc „eurokomunizmu” w latach 70. XX w. i „pierestrojki” Gorbaczowa dekadę później, będzie utrzymywać Đilasa w tym przekonaniu. Były współpracownik Tity dostrzeże w nich jedynie siły rozkładowe, pozwalające „zrzucić skorupę stalinizmu” i wprowadzić demokrację. Zgodnie z teza, że łagodzenie „wpływu choroby jest wielkim krokiem naprzód dla tych, którzy na nią cierpia”" ${ }^{60}$. Zastanawiać może jednakże fakt, że Đilas całkowicie pomija milczeniem doświadczenie polskiej „Solidarności”, oddziaływanie tej organizacji na dezintegrację komunizmu i jego upadek u schyłku lat 80 . XX stulecia.

Ostatecznie Đilas proponuje tylko reformy, przekształcenia demokratyczne. Nie ma złudzeń, by jakiekolwiek wspólnoty ludzkie czy systemy polityczne mogły ziścić postulaty marksistowskie, a więc doprowadzić do zaniku państwowości, podziałów klasowych, nierówności społecznych, do likwidacji własności prywatnej ${ }^{61}$ i wprowadzenia „sprawiedliwego wynagrodzenia” za pracę $^{62}$. W rezultacie głosi potrzebe „odejścia od zracjonalizowanego szaleństwa i zorganizowanego niebezpieczeństwa tzw. systemów «komunistycznych»", przynoszacych zagrożenia wynikające $\mathrm{z}$,utopijnej wiary w «doskonałe społeczeństwo»”. Eliminacja tych zagrożeń prowadziłaby „przez [ustanowienie - M.J.Z.]

${ }^{59}$ M. Djilas, Une societé imparfaite..., s. 287.

${ }^{60}$ Dżilas o Gorbaczowie..., s. 7 i 39.

${ }^{61}$ M. Djilas, Of Prisons and Ideas..., s. 141 i n. Zob. także: tenże, Parts of Lifetime, ed. by M. and D. Milenkovitch, New York 1980, s. 270; C.L. Sulzberger, Paradise Regained. Memoir of a Rebel, New York-Westport-Connecticut-London 1989, s. 27. Sulzberger cytuje na tej stronie następującą wypowiedź Đilasa z września 1984 r.: „Myślę, że z punktu widzenia teoretycznego bezklasowe społeczeństwo byłoby możliwe, ale tylko wtedy, gdyby ludzkość była doskonała”. Jednakże „ludzie nie są doskonali. Stąd takie społeczeństwo byłoby możliwe tylko wśród aniołów lub robotów”. Zob. także tamże, s. 32, 133.

62 „Nie ma, nigdy być nie może sprawiedliwego wynagrodzenia. Identycznie tak, jak nigdy być nie może doskonałego społeczeństwa lub społeczeństwa bez państwa. Eksploatacja jest nieunikniona, jest naturalną cechą życia [choć - M.J.Z.] tak samo jest uzasadniona walka przeciwko wyzyskowi. Człowiek utrzymuje się przy życiu zmagając się zarówno z naturą społeczeństwa, jak i swoją własną. To samo można powiedzieć o równości i nierówności. Obie wyrastają i upadają w ciągu nieustannej walki”. M. Djilas, Of Prisons and Ideas..., s. 159. Powyższe stwierdzenia są bardzo dobrą ilustracją ogólnego rozumowania Đilasa. Taki czy inny podział dochodów, mniej lub bardziej sprawiedliwy bądź niesprawiedliwy, podobnie jak równości i nierówności społeczne, zależy od idei i wysiłków ludzkich, niechęci czy skłonności do reform, przynoszących wszakże ograniczone rezultaty. 
systemu demokratycznego socjalizmu" ${ }^{63}$. W ujęciu Đilasa byłoby to równoznaczne z powstaniem „otwartego społeczeństwa, tj. społeczeństwa uznającego wszystkie formy i dazżenia, które można pogodzić w ramach instytucji działajacych zgodnie z prawem”. Socjalizm byłby „formą społeczeństwa”, w którym wolna, swobodna gra, swoista rywalizacja różnych grup i warstw umożliwiałaby „sprawiedliwy podział "narodowego placka»". Istnienie takiego systemu stałoby się możliwe jedynie w warunkach „mieszanej gospodarki”, respektujacej „wolność własności prywatnej” ${ }^{64}$. Byłoby to „społeczeństwo niedoskonałe”, pozbawione wiary, że ,jednym pociagnięciem chirurgicznego noża" absolutne idee mogą doprowadzić do natychmiastowego, całkowitego „uleczenia” ludzkości. Niemniej takie społeczeństwo, ożywiane „humanizmem”, „wyobraźnią” i „marzeniami”, miałoby szanse stałej naprawy, ciagłej reformy „,bez upustu krwi w bratobójczych walkach” ${ }^{65}$.

Generalnie, oceny i wnioski Đilasa mogą budzić ambiwalentne odczucia. Niewatpliwie trafne i przenikliwe okazały się jego przewidywania w sprawie kryzysu i zaniku idei (utopii) marksistowskich, a także dezintegracji oraz dyferencjacji krajów i społeczeństw rządzonych przez „nową klasę”, a w rezultacie - w sprawie rozpadu komunizmu. Đilas nie pomylił się również twierdząc, że rozpad systemu nastapi głównie w rezultacie ewolucji, bez użycia siły, przemocy, gwałtów, rewolucyjnych środków ${ }^{66}$. Niemniej jego wiara w pozytywna, sprawczą moc nowych, niemarksistowskich idei czy utopii, mających inspirować reformy, prowadzić do stopniowego i powolnego, ale widocznego, rzeczywistego ulepszania „niedoskonałego społeczeństwa”, obecnie, w dobie potężnego kryzysu światowego, może się wydawać przesadna, być może - nieco naiwna. Pozbawiona koniecznego, jak się wydaje, zastrzeżenia, że progresywna potęga idei i utopii ma jednakże swoje granice, że nie pojawia się automatycznie w każdej sytuacji. Taka wiara mogła być uzasadniona w okresie powstawania cytowanych prac Đilasa, a więc w „złotym wieku kapitalizmu” ${ }^{\text {, }}$, charakteryzującym się rze-

${ }^{63}$ Tamíe, s. 52.

${ }_{64}$ Tamże, s. $152-153$.

${ }^{65}$ M. Djilas, Une societé imparfaite..., s. 16-17.

${ }^{66}$ Oczywistym wyjątkiem byłaby tu Rumunia. Jeśli chodzi o Jugosławię, to krwawe konflikty wojenne pojawiły się tam już po rozpadzie SKJ w styczniu 1990 r., a także struktur władzy komunistycznej w poszczególnych republikach. Były związane z rozkładem nie tyle systemu komunistycznego, ile samego państwa, zob. M.J. Zacharias, Komunizm, federacja, nacjonalizmy..., s. 439 i n. Trafność poglądu Đilasa w pewnym stopniu może potwierdzać także ewolucja sytuacji w Chinach. Przetrwaniu władzy komunistycznej w tym państwie towarzyszyło przecież stopniowe wprowadzanie zasad gospodarki rynkowej, zob. M.E. Szatlach, Strategia gospodarcza wspótczesnych Chin - wybrane aspekty polityki wewnętrznej i międzynarodowej, [w:] Historia, polityka, stosunki międzynarodowe..., s. 174 i n.

${ }^{67} \mathrm{~W}$ „złotych latach” kapitalizmu w świecie zachodnim (jak to określano we Francji - Les trentes glorieuses: ou, La Révolution invisible de 1946 à 1975; taki był tytuł książki Jeana Fourastié z 1979 r., opisującego społeczną i gospodarczą transformację Francji w tym okresie), a więc w latach od zakończenia II wojny światowej po połowę ósmej dekady 
czywistym rozwojem, któremu sprzyjała, jak pisze Eric Hobsbawm, tzw. gospodarka mieszana ${ }^{68}$ i praktyki społeczne oraz polityczne welfare state. Mogła być uzasadniona także później, w latach 80 . XX w., kiedy to procesy globalizacji, zmiany ogólnego układu sił na świecie, związane z powstawaniem nowych i osłabianiem starych ośrodków bogactwa i mocy politycznej, a także wszystko to, co niezbyt trafnie i niezbyt precyzyjnie nazywa się neoliberalizmem, nie stało się jeszcze, w znacznej mierze, siłą hamująca powstawanie nowych idei i możliwości pozytywnej ewolucji procesów gospodarczych, społecznych i politycznych; siłą obezwładniająca środowiska opiniotwórcze i polityczne, a zarazem sprzyjająca petryfikacji społeczności, które „idee stworzenia lepszego świata” zastępuja „zdobyciem lepszego telewizora”, jak napisał jeden z komentatorów zamieszek w Londynie w sierpniu $2011 \mathrm{r}^{69}$ Dominacja takich aspiracji naturalną koleja rzeczy musi sprzyjać wygaszaniu idei, utopii aspirujących do zmiany i naprawy świata. Niewątpliwie, przynajmniej $\mathrm{w}$ pewnym stopniu, jest to pochodna szerszego zjawiska, zauważonego m.in. przez francuskiego socjologa Alaina Touraine'a, stwierdzającego że „globalizacja gospodarki wymknęła się spod jakiejkolwiek kontroli”, doprowadzając „do sytuacji, że nie istnieje żaden aktor społeczny, polityczny, kulturalny, zdolny do zarządzania nią, do wpływania na jej transformację". W rezultacie zmienia się „rola instytucji, które [...] są sposobem, w jaki społeczeństwa zarządzają swoimi zasobami, tworząc programy gospodarcze, edukacyjne, kulturalne. To wszystko się skończyło" . Jeśli tak, to rozważania Đilasa w sprawie ożywczego, pozytywnego oddziaływania idei, reform i transformacji społecznych zaczynają napotykać wielkie, być może nieprzezwyciężalne przeszkody. Można by zaryzykować hipotezę, że albo w ogóle przestają się pojawiać, albo wykazują swoją bezsilność. Nie ma bowiem osobistości ani instytucji ${ }^{71}$ zdolnych przezwyciężyć wpływy oraz interesy znaczaccych

XX w. W okresie dynamicznego rozwoju gospodarki kapitalistycznej, w kształcie dalekim od dzisiejszego tzw. neoliberalizmu, pogrążonego w kryzysie, zob. E. Hobsbawm, Wiek skrajności. Spojrzenie na krótkie dwudzieste stulecie, Warszawa 1999, s. 241 i n.; T. Judt, Powojnie. Historia Europy od roku 1945, Poznań 2008, s. 383 i n.

${ }^{68}$ E. Hobsbawm, dz. cyt., s. 251 i n.

69 J. Harper, Białe śmieci, „Polityka”, 14 IX - 20 IX 2011, nr 38 (2825), s. 52. Ta metafora dobrze odzwierciedla obecną bezsilność, a przede wszystkim brak nowych idei, które zgodnie z logiką myślenia Đilasa powinny się pojawiać głównie w okresie przesileń i kryzysów. Wydaje się, że nie znając mechanizmów i destrukcyjnych mocy obecnej formy kapitalizmu, a więc tzw. neoliberalizmu, Đilas nie mógł przewidzieć takiej sytuacji.

${ }^{70}$ Jesteśmy w punkcie zero. Rozmowa z profesorem Alainem Touraine'em, „Polityka”, 14 IX - 20 IX 2011, nr 38 (2825), s. 54.

${ }^{71}$ Mam na myśli brak instytucji europejskich czy nawet ogólnoświatowych. Istniejace władze państwowe tym bardziej nie są w stanie pohamować negatywnych procesów gospodarczych i społecznych, mających charakter globalny. Takie stwierdzenie może się wydawać nieco ryzykowne, ale uzasadnione przynajmniej w odniesieniu do tej sytuacji, z którą mamy do czynienia obecnie. 
środowisk zainteresowanych w utrzymaniu status quo oraz sprawić, by idee, utopie i przemiany ewolucyjne zostały przyjęte i poddane próbie realizacji ${ }^{72}$.

Należałoby jednakże podkreślić, że rozważania Đilasa dotyczą głównie konkretnej rzeczywistości - politycznej, społecznej, gospodarczej, słowem ustrojowej, zgodnie z logika jego myśli osadzonej w „ziemskim” kontekście bytu, pozbawionym „kosmicznego” wymiaru. Niemniej w pewnym stopniu wiążą się również z refleksją sięgającą transcendentalnych uwarunkowań ludzkiego myślenia, przeżywania i działania; natury wszechświata, stopniowo odsłaniającego swoje tajemnice w dobie coraz częstszych lotów kosmicznych. W tej perspektywie - stwierdza Đilas - „dzisiejsze idee, dzisiejsze dogmaty i praktyczne ideologie będą się rozpadać w podmuchach ziemskiego pyłu”. „Kosmiczna przyszłość" należy do świata idei, filozofii i religii, ale funkcjonujących w innym wymiarze. W rezultacie przyczyni się to do tego, że „szczęście” stanie się bardziej prawdopodobne niż kiedyś, możliwości ludzkie zaś - bezgraniczne. „Na naszych oczach powstaje epoka przywódców, nauczycieli i realistów obdarzonych taką żywotnością i głębokością dostrzegania, jakiej świat nie widział". Đilas pisze, że rozważania w komunistycznych celach więziennych uzmysłowiły mu, że narody, społeczeństwa, kraje i „kosmos” nie posiadają żadnych „centrów [? - M.J.Z.]". W zestawieniu ze wszechświatem ziemskie idee nie mają znaczenia, rozmywają się w nieskończoności. „W konfrontacji z bezkresną rzeczywistością kosmosu nie można wykluczyć, że «klasowe» i «narodowe», «komunistyczne» i «kapitalistyczne» utopie znikna, tak jak inne, które dzisiaj przemiennie inspirują i niszczą ludzkie dusze i systemy”. W „kosmicznej przyszłości” świadomość i „dojrzałość” ludzka „staną się bardziej naukowe [...] choć człowiek nie przestanie być marzycielem”. Skonfrontowany z rzeczywistością nieskończoności

${ }^{72}$ Prezentowany artykuł został napisany we wrześniu i październiku 2011 r. W nawiązaniu do treści poprzedniego przypisu należałoby dodać, że nie jesteśmy w stanie przewidzieć, czy w przyszłości pojawią się jakiekolwiek nowe idee oraz utopie - w tym sensie, jakie nadaje im Đilas. Idee i utopie zdolne wpłynąc na pozytywną ewolucję kapitalizmu i liberalnej demokracji, a więc dwóch podstawowych składników określających współczesną cywilizację zachodnią. Niemniej mierne efekty reform, z którymi szli do władzy prezydenci Francji i USA, a więc Nicolas Sarkozy i Barack Obama, niepowodzenia neoliberalnych reform i porządków w Irlandii, patologie gospodarcze, społeczne i polityczne we Włoszech, Hiszpanii i Portugalii, głównie zaś w Grecji, mogą nastrajać sceptycznie, a nawet pesymistycznie. Tak samo jak obecne protesty „oburzonych”, wysuwających jedynie populistyczne żądania, nie przynoszące, „oprócz utopijnych haseł «koniec z kapitalizmem»” żadnych „recept na rozwiązanie kryzysu”, zob. W. Lorenz, współpraca J. Przybylski, Dojrzewanie nowej lewicy, „Rzeczpospolita”, 22-23 X 2011, nr 247 (9063), dodatek „PlusMinus”, s. P12. Podobnie pisze Krzysztof Pilawski stwierdzając, że „oburzonych nie zrodziła idea, lecz «materia» - gwałtowne pogorszenie sytuacji bytowej młodych ludzi”, zob. K. Pilawski, Oburzeni na kapitalizm. Rozmowa z prof. Jerzym Kochanem, „Przegląd”, 30 X 2011, nr 43 (617), s. 6. 
może stać się większym utopista, osobą zdolniejszą i bardziej skłonną do różnorodnych przeżyć religijnych, jednostką doskonalsza. W związku z tym Đilas wyraża przekonanie, widoczne również w ,ziemskich" rozważaniach, że człowiek nie mógłby rozwinąć swoich możliwości na tak wielką skalę, gdyby dążenia do „absolutnej prawdy i ludzkiej doskonałości nie wyrażały jego natury”. Stanowia one siłę napędowa jego działań, marzeń i wysiłków prowadzacych do powstania lepszej przyszłości, choć powtórzmy - nie umożliwią mu budowy „doskonałego świata” - ani w „ziemskiej”, ani w „kosmicznej”, nieskończonej perspektywie. W nowej rzeczywistości, wyrażającej się w stopniowym wykraczaniu człowieka poza swą tradycyjna, „ziemską" hemisferę, utopie i rzeczywistość będą się do siebie zbliżać w przenikaniu „wiedzy i świadomości”, ale nigdy się nie połączą i nie staną się identyczne. „Absolutna idea”, w „kosmicznych” rozważaniach Đilasa utożsamiana z Bogiem ${ }^{73}$, nie zostanie urzeczywistniona, podobnie jak szczęście, niezależnie od tego, jak głęboko postapi ludzka „penetracja” wszechświata. Nie tylko dlatego, że w rezultacie egzystencja człowieka straciłaby, zdaniem Đilasa, jakiekolwiek sensowne uzasadnienie. Głównie dlatego - pisze autor O więzieniach oraz ideach - że byłoby to sprzeczne zarówno z ludzką natura, jak i charakterem przestrzeni „kosmicznej”. Rzeczywistość społeczna jest „bezkresna, niepojęta”. Liczyć można jedynie na to, że „kosmiczny człowiek” zachowa swoje „dotychczasowe cechy, te same słabości, te same zalety" "74. Zgodnie z logika wywodów Đilasa, ludzkie dążenia do doskonałości także we wszechświecie będą urzeczywistniane jedynie stopniowo, na drodze ewolucji, częściowo, bez możliwości osiagnięcia absolutu ${ }^{75}$.

Nie jesteśmy w stanie stwierdzić, czy w „kosmicznej” perspektywie idee i utopie, reformy i transformacje opisywane przez Đilasa mogłyby natrafić na te same przeszkody, co sygnalizowane powyżej, w odniesieniu do „ziemskiej”, m.in. przez Touraine'a. Wydaje się, że w swoich rozważaniach dawny współpracownik Tity zbyt daleko wybiega w przyszłość, zbyt wyraziście daje upust swojej futurologicznej fantazji. W rezultacie jego rozmyślania i przepowiednie dotyczące przyszłości tracą swoją dotychczasową ostrość i precyzję. Stają się mało wyraziste, nieco sztuczne, a także niezbyt przekonujące, pozbawione jasnej i rzeczowej myśli, charakteryzującej „ziemskie” rozważania Đilasa. Są zbędne, bo nie wnoszą niczego nowego. Co nie oznacza, że nie ma w nich także trafnych myśli, występujacych we wcześniejszych przemyśleniach Đilasa.

${ }^{73}$ Jak się wydaje, tu pojmowanym jako Idea, bezosobowy byt, mechanizm wprawiajacy cały świat w ruch. Trzeba bowiem pamiętać, że doceniając wagę wierzeń religijnych, Đilas przedstawia się jako ateista, zob. C.L. Sulzberger, dz. cyt., s. 30.

74 M. Djilas, Of Prisons and Ideas..., s. 166.

75 Tamże, s. 160 i n. 